\title{
The 1915 Mets Yeghern (Genocide) of Armenians: History and Contemporary Problems
}

\author{
Ashol Melkonyan \\ Institute of History, RA NAS
}

\begin{abstract}
The present article aims at discussing some facts from the history of the Armenian Genocide - the most horrendous act of exterminating a race from its Motherland. The discussion of the historical facts presented below spreads light on the actual reasons of the Armenian Genocide and its pre-planned nature which has so far been and is still being officially rejected by the Turkish authorities of today. An attempt is also made to reveal the essence of the fraudulent offer of the official Turkey to leave the discussion of the question to historians.
\end{abstract}

Key words: The Armenian Genocide, the Armenian Question, annihilating the Armenians, Pan-Turkism, the Great Turan, mass slaughters, Young Turks, deportations, international recognition and compensation.

\section{Introduction}

Most part of the 400 thousand. sq. km. historical Armenia - Western Armenia, appeared under the cruel domination of the Ottoman Empire in the $16^{\text {th }}$ century. Eastern Armenia first appeared under the rule of Persia and then, in 1830s - under the rule of Russia. At the conclusion of the Russo-Turkish war of 1877-1878, when most of the Western Armenian provinces formerly occupied by Russia again passed to Turkey. pressured by Russia and then by the great European powers, a special provision was introduced in the peace treaties of San Stefano and Berlin in 1878. According to the provision the Turkish Government was under the obligation of undertaking and carrying out reforms for the Armenians who had remained under the Ottoman yoke. In international dimplomacy the question of these reforms was termed as "the Armenian Question".

However, very soon the Turkish Sultan Abdul Hamid II not only forgot about the Berlin Congress provision 61 but also offered a unique way of implementation of the provision - he chose to solve the Armenian question by annihilating the Armenians. Hamid was the first to make Pam-Islamism and Pan-Turkism a state ideology: the first assumed unification of all Islamic and the second - of all Turkic peoples under the flag of Turkey and waging a holy war against infidel Christians - the gavurs. Armenians who geographically wedged the way to the plans of Pan-Turkism were targeted in particular.

\section{The Period of Abdul Hamid}

In order to "solve" the Armenian question Hamid instigated the contumacious nomadic Kurdish tribes to assault Armenians. In 1891 he established special Kurdish cavalry regiments and named after himself - Hamidiye. The Hamidiye members received government salaries and were authorized to freely plunder and loot the Armenian popu- 
lation. This is how the Armenian-Kurdish conflict was initiated. A brutal regime of terror was set up in the country. Strict censorship was imposed.

The years of 1894-1896 witnessed the assaults of the Hamidiye troops upon the villages and towns of Western Armenia. Mass slaughters of Armenians were organized throughout the Empire, 300 thousand people perished. Thousands of Western Armenians emigrated to different countries; about 100 thousand - to Russia, 200 thousand - to Europe and America. To escape the pogroms many Armenians were forced to adopt Islam. This event was one of the first manifestations of genocide (geno-race, tribe, cidekilling) in the world. Genocide is a state-organized mass crime against a nation or a religious community, aiming at a total annihilation of the given ethnic or religious group.

\section{The Entrance of the Young Turks on the Scene}

Besides the Turkish subject nations there were many young Turk activists educated in Europe who raised their voices against the bloody regime of Sultan Hamid in the late $19^{\mathrm{H}}$ and early $20^{\mathrm{th}}$ centuries. Their popular effort resulted in the establishment of the parties "Union and Progress" and "Young Turkey". Unfortunately, the Young Turk slogans on democracy, ethnic equality and their struggle against Hamid inspired Armenian, Greek, Jewish, Arab and other political circles to join forces with the Young Turks to fight a common enemy - Sultan Hamid.

In July, 1908 the Young Turks, backed by separate political groups of Turkish subject nations, seized the power in a coup. A constitutional monarchy was established. Promises of ethnic and social equality were made. But soon the Young Turk government showed its real racist tendences, actually adhering to the nationalistic policy of Hamid. 30 thousand people fell victim to massacres organized in Adana and other parts of Cilicia in April, 1909.

In a congress held in the Greek city of Thessaloniki in 1911 the Young Turks adopted a resolution which stated the intention of turning Turkey into a Turkish state and the necessity of ethnic cleansing. A decision was made under Talaat (the Interior Minister), Enver (Minister of Military Affairs), Jemal (Minister of Maritime Affairs) to try, in case of war, to finally resolve the Armenian question by completely annihilating the nation and realizing their Pan-Turkish plan of establishming the Great Turan.

Representatives of different nationalities were killed during World War I (19141918). However, considering the population density, no other nation suffered so many losses as the Armenians did. It was the world's first organized mass crime - a genocide.

On April 15, 1915 the Young Turk committee adopted a resolution intending

- to disarm the Armenian soldiers of the Ottoman army accusing them of high treason;

- to arrest and exile Armenian intellectuals from all Armenian-populated regions;

- to deport the Armenian civilian population and to exile them to the Syrian deserts on the pretext of physical and property security reasons;

- to send the copies of the resolution to governurs.

The copies of the command were sent 10 all governors. Those who refused to carry out the above-mentioned orders, regardless of nationality, were subject to liability. 


\section{Beheading the Nation}

April 24 (moming of 25). 1915 saw the arrest of numerous Armenian intellectuals (according to official Turkish data 2345 people); political, national, religious leaders, teachers, doctors and other professionals in Constantinople. Among them were the Ottoman MPs Grigor Zohrap and Vartkes, the writers Daniel Varuzhan, Ruben Sevak, Siamanto, Telagadintsi, Yerukhan and others. Nazaret Chaush in Zeitoun and Vramian in Van fell victim to the plot.

Armenian intellectuals were exiled in three directions - Chankri, Chorum, Ayash. Varuzhan and Sevak were killed near Chankri, Zohrap - near Urfa. Approximately 200 thousand Armenians in the Turkish army were disarmed and executed by firing squad. The famous Armenian composer Komitas who witnessed the Turkish atrocities and miraculously escaped death, acquired mental disability.

A Special Organization for deportation (Tesskilât-ı Mahsusa) was set up. Young Turk Committee member Behaeddin Shakir coordinated special chete forces consisting of intentionally released convicts to raid on Armenian villages and displace the population. Mass deportations started in May, 1915. From May to October Erzurum, Trabzon, Van, Bitlis, Diyarbakir, Sivas, Adana, Iconium, Aleppo and other provinces were cleaned up of Armenians.

On June 15 twenty Armenian Hnchak party members, among them the famous activist Paramaz (Matheos Sargsian) were hunged in Sultan Bayazid Square, Constantinople. The call of the Cilician Catholicos Sahak Khapayan to accept displacement amenably, turned out to be fateful. The whole of Cilicia, with the exception of Musa Ler, took the path of deportation. The caravans of Western Armenian deportees stretched to Erzincan, Derjan, Kharpert, Malatya, Aleppo, Der Zor. The worst massacres took place when crossing the Euphrates - near the town of Kamakh and in the Syrian desert of Der Zor. Only the cities of Constantinople and Smyrna survived mass deportations as the Turks feared European intervention.

Only 10-20 thousand Armenians (from 500 thousand deportees in Der Zor) survived the disaster. Hundred of thousands people left their Motherland and found refuge in different countries of the world.

\section{The German Factor and the Armenian Genocide}

According to the German humanist Dr. Johannes Lepsius an estimated 1.5 million Armenians perished in the Ottoman Empire. Apart from this, immense material losses were caused - 15 million francs. The Armenian districts of 170 towns, 2800 villages, 2350 churches, 1500 schools and colleges were destructed.

When the US Ambassador to the Ottoman Empire Henry Morgenthau expressing his complaints on the mentioned atrocities to Talaat Pasha said that he would have to be answerable to the Armenians for what he had done, the latter replied cynically that there were no more Armenians to be answerable to, and that he had done more in three months than Sultan Hamid did in three decades.

The fault of Turkey's ally Germany in waging the Armenian Genocide was no less gross than the Turkish one. Germany constantly backed and encouraged the Young Turks. 
Only individual humanists like Y. Lepsius, A. France, F. Nansen, V.Bryusov, A. Block and others raised their voices in defence of Armenians.

A number of Armenian avengers (Soghomon Tehlirian, Arshvir Shirak, Aram Yerkanian, Artashes Gevorgian and others) committed assassinations of the Genocide orchhestrators Grand Vizier Talaat, Minister of Maritime Affairs Jemal, leader of chete regiments Behaeddin Shakir, Prime Minister Said Halim, governor of Trabzon Jemal Azmi and others. The operations are known as "Nemesis" (in classical mythology the Greek goddess of vengeance).

Thus the Armenian Question was "resolved" through the Genocide of Armenians. The Armenian people not only suffered tremendous physical and material losses but also was deprived of the Motherland, the historic homeland. Later the issue of the international recognition of the Armenian Genocide and the compensation for it was formulated as the Armenian Cause (Hay Dat).

As Armenia lacked independent statehood, for seventy years (1921-1991) the pursuit of the Armenian Cause became "monopolized" by the diaspora Armenians. Noteworthy are the years of 1945-1947 when, on behalf of the Armenians, the issue of the Armenian lands in question was again raised but this time within the frames of the Soviet foreign policy. However, it was strongly opposed by the Anglo-Americans. Soon the issue faded into oblivion in the USSR. Moreover, the Khrushchev regime of 1950 s declined any territorial claim to Turkey. The Armenian Cause became a taboo in the Soviet Union.

Since 1965, after the official commemoration of the 50" anniversary of the Armenian Genocide, Armenia has participated in the pursuit of the Armenian Cause. In this, certain role was played by a number of patriotic Soviet Armenian leaders, by Yakov (Hakob) Zorabian in particular. Since 1965 Armenia and the diaspora Armenians have joined in the struggle. The remote country of Uruguay was the first to officially recognize and condemn the Armenian Genocide.

The European Parliament, to block Turkey's entry to the Council of Europe, "suddenly" remembered the long-forgotten Armenian Cause. Among other requirements Turkish authorities were submitted a written demand to recognize and condemn the Armenian Genocide to achieve access to the prestigious European organization. The resolution stated that by its groundless denial of the Genocide Turkey was depriving Armenians of the right to their own history and that so far the historically proven Armenian Genocide has not been subject to political conviction and has not achieved adequate compensation.'

In 1991, after Armenia was declared independent, Armenia's first President Levon Ter-Petrossian and the Ter-Petrossian-led political party Armenian National Movement (ANM), due to a cautious approach to the problem, made a decision not to give priority to the Genocide issue in the foreign policy of Armenia as it could jeopardize the independence of the young country.

This policy radically changed after 1998 when Robert Kocharian took office. He raised the question dignifiedly in an Istambul summit, in the UNO and in the Parliamentary Assembly of the Council of Europe. The issue was repeatedly discussed in the RA Foreign Minister's speech and other official presentations. The new authorieties perceived the issue to be a serious argument against Turkey and in favour of Armenia in 
various international organizations. Actually the change of the official approach to the problem worked, and many countries, official institutions and organizations as well as individuals started to condemn the Genocide during the period of 1998-2000, among them the parliaments of Belgium, France, the Republic of Nagorno-Karabagh, Sweden, Italy, Lebanon, the municipalities of New York and Rome, Pope John Paul II. Since 1965 the Armenian Genocide had been recognized by only five countries (Uruguay, Cyprus (1982), Argentina (1985), Russia and Greece (1995), and most of them had done this on the $60^{\mathrm{H}}$ and $70^{\mathrm{H}}$ anniversaries of the Genocide.

In 2001, under the auspices of the US State Department, the so-called TurkishArmenian Reconciliation Commission (TARC) commenced its activity. Interestingly enough, during the whole period of the TARC activity a trend to involve the Armenian party into Genocide debates was observed. The initiators were different Turkish, European and American organizations, research and educational institutions. It was quite clear that by involving the Armenians into such debates, moreover, by "reconciliation" (if ever there can be a reconciliation between the executor and the victim) the Turkish diplomacy was trying to solve several problems; firstly, for Armenian scholars, particularly historians, starting a scientific debate over the issue of Genocide with the Turks meant to unwillingly and unwittingly support those people who were doubtful of the fact that what had happened could be characterized as a genocide. This was actually a "zero starting position" for Armenians.

Secondly, it was a wonderful opportunity for the Turkish party to convince the world that as far as Armenian scientific disputes were in progress, there could be no need to address the Genocide issue to parliaments or other structures. Well, the issue could be again referred to after the disputes were over and solutions found. It goes without saying that with the active participation of the West (the motives could have been noble) a trap was being set for the Armenian party.

Unfortunately, despite assurances of "no concession over the Armenian Cause" the Armenian party, which was represented by famous activists (ex Foreign Minister, an ANM member Alexander Arzumanian, the Russian-Armenian political analyst Andranik Mihranian, American-Armenian lawyer Van Grigorian and others) eventually found itself tricked and trapped and was forced to lean towards the termination of the activity of the infamous TARC. The Armenian members of the Commission, to disguise their failure, issued a statement, according to which the Commission had achieved certain positive results and they had made a step forward in the direction of relaxation of Armenian-Turkish tension.

In fact, the infamous Commission did much harm to the process of the international recognition of the Armenian Cause. There were cases when parliaments of different countries (eg.Germany, Austria, Canada, etc.) removed the Genocide issue from their agendas. The reasoning was that they had to await until the TARC had made its decision.

It is no coincidence that no country discussed and recognized the Armenian Genocide in the period of the TARC activity from November 2001 to 2003. It was only when the TARC had de facto been dissolved that during the period of December 2003 to December 2004 Switzerland, Canada, Slovakia, the Netherlands referred to the Genocide again and officially condemned it. In 2004, in connection with the negotiation process on Turkey's entry into the EU, the Issue of the Armenian Genocide was again recirculated. 


\section{Conclusion}

Thus, an official, governmental approach and rejection of fruitless Armenian-Turkish scientific dialogue is essential for the solution of the Armenian Cause. It is no accident that even today, when the issue has turned from scientific into political, the Turkish authorities, in their endeavour to achieve oblivion for the question of Genocide, are seeking ways to leave it to historians. There is no doubt that a forgotten crime gives birth to a new crime. When Adolf Hitler was warned by his supporters that Germany would have problems with the civilized world in case of a Jewish Genocide, he insisted on the opposite, asking, "Who remembers the Armenian Genocide of 1915."

Turkey's recognition of the Armenian Genocide and compensation is actually a solution to a national security problem for our small land of Armenia. Currently, Turkey not only refuses to recognize the Genocide, but also is trying to convince the world that it were the Armenians who massacred the Turks in 1915. Hopefully, in the years to come, parliaments of many other states (in addition to 25) will recognize and condemn the Armenian tragedy, thus opening a way to justice and victory of democracy and will provide reliable guarantees of security to geopolitically landlocked Armenia.

\section{Notes:}

1. Barseghian. L.A. (2000) Chronology of Public Conviction and Recognition of the Armenian Genocide (1915-2000). Yerevan, p. 32.

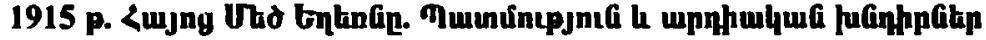

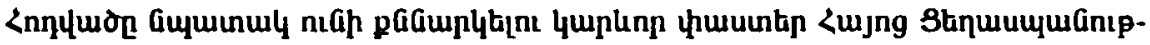

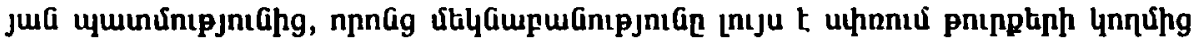

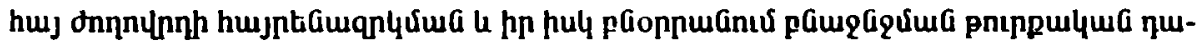

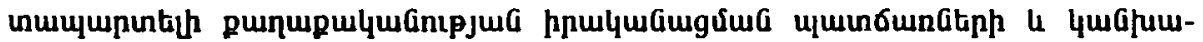

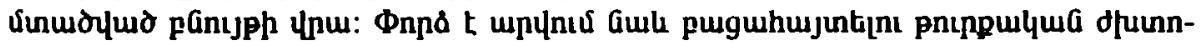

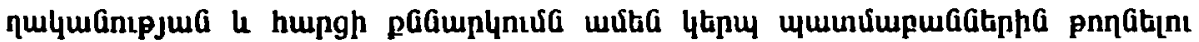

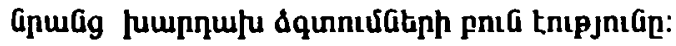

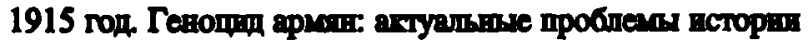

Цель статьи - рассмотрение важных фактов истории - геноцида армян, фактов, свңдетельствующих о запланированном турецкими властями наскльственном уничтожении армянского народа, лишении его права жить на собственной земле. В статье раскрываются причнны подобной политики, объясняется подлинная суть непрнзнания официальной властью Турции геноцида армян, что позволяет турецким историкам пронзвольно и несправедливо толковать факты историн. 